\title{
Spatial distribution of dairy heifers' dung in silvopastoral systems
}

\section{Roberta Aparecida Carnevalli ${ }^{1 *}$ (iD) Andrea Cristina Tavares de Mello² ${ }^{\text {(DD }}$ Luciano Shozo $^{3}$ (D) Steben Crestani ${ }^{4}$ (D) Admar Junior Coletti ${ }^{2}$ (D) Camila Eckstein ${ }^{5}$ (D)}

\author{
${ }^{1}$ Empresa Brasileira de Pesquisa Agropecuária, Embrapa Agrossilvipastoril, 78550-970, Sinop, MT, Brasil. E-mail: roberta.carnevalli@ \\ embrapa.br. "Corresponding author. \\ ${ }^{2}$ Universidade Federal de Mato Grosso (UFMT), Sinop, MT, Brasil. \\ ${ }^{3}$ School of Plant, Environmental and Soil Sciences, Louisiana State University AgCenter, Baton Rouge, LA. \\ ${ }^{4}$ Atlântica Sementes/Nuseed, Curitiba, PR, Brasil. \\ ${ }^{5}$ Universidade Federal de Minas Gerais (UFMG), Belo Horizonte, MG, Brasil.
}

ABSTRACT: Ruminants vary their walking trajectory according to the positioning of the trees in integrated systems, which can determine the concentration of dung deposition at certain locations. The aim of this study was to map the distribution of feces and the behavior of dairy heifers in sunny and shaded areas. This experiment was carried out in Mato Grosso, Brazil, where the main grazing conditioner is shade due to the presence of trees in the pastures. Shading levels used were: full sunlight (control), moderate shade (338 trees ha ${ }^{-1}$ ) and intensive shade (714 trees $\mathrm{ha}^{-1}$ ) in randomized complete blocks. The experimental period was divided into three evaluation periods based on rainfall distribution: rainy period $=$ December 2012; transition period $=$ March 2013 and dry period $=$ June 2013. Animal behavior assessments and dung distribution mapping were performed. The full sunlight system displayed a higher concentration of feces patches at sites near the gate, cow drinkers and fences opposite the gate. Heifers picked shaded places for ruminating and idleness. The major concentration was reported in the central area and under trees, in shaded systems. There were places with greater feces concentrations, but when the pasture had trees, deposition did not only happen underneath trees but also in places under their influence. The distribution was more homogeneous when trees were present in large quantities. The shaded area available in pastures affects spatial distribution of dung, stimulating uniformity. Key words: pasture litter, feces patches, shade, heifers.

Distribuição espacial de fezes de novilhas leiteiras em sistemas silvipastoris

RESUMO: Os ruminantes variam a trajetória de sua caminhada de acordo com o posicionamento das árvores em sistemas integrados. A deposição de fezes pode estar mais ou menos concentrada em determinados locais, de acordo com a disposição desses condicionadores de pastejo que definem o caminhamento animal. O objetivo deste experimento foi mapear a localização e a distribuição de fezes de bezerras leiteiras de acordo com seu comportamento afetado pela disponibilidade de áreas ensolaradas e sombreadas. Este experimento foi conduzido em Mato Grosso, no Brasil. O principal condicionador de pastejo foi o sombreamento promovido pela presença de árvores nas pastagens. Foram impostos níveis de sombreamento: pleno sol (controle), sombreamento moderado (338 árvores ha ${ }^{-1}$ ) e sombreamento intenso (714 árvores $\mathrm{ha}^{-1}$ ) em blocos completos casualizados. O periodo experimental foi dividido em períodos de avaliação com base na distribuição das chuvas: Período Chuvoso = dezembro de 2012; Período de Transição = Março de 2013 e Período Seco = Junho de 2013. Foram realizadas avaliações de comportamento animal e mapeamento da distribuição das placas de fezes na área. Para atividades de ruminação e lazer, as novilhas preferiram os locais mais sombreados. O sistema pleno sol promoveu maior concentração de placas de fezes em locais próximos a porteiras e bebedouros, no lado oposto ao da porteira. Nos sistemas sombreados, a maior concentração foi na área central e sob sombra. Havia locais com maior concentração de fezes, mas quando havia árvore na pastagem, a deposição não acontecia apenas abaixo da árvore, mas também nos locais sob sua influência. A distribuição foi mais homogênea quando as árvores estavam em maiores quantidades. A área de sombra disponível no pasto afeta a distribuição espacial do esterco estimulando a uniformidade.

Palavras-chave: perdas de pastejo, placas de fezes, sombra, novilhas.

\section{INTRODUCTION}

The silvopastoral system has been used by dairy farmers in tropical areas, mainly, because this kind of system provides adequate environmental conditions for dairy cows. The main feature of a tropical region is an extreme climate due to high temperatures and solar radiation, factors that diminish animal production. In these situations, the introduction of trees can improve the microclimatic conditions, and can determine a change in the ruminants' walking trajectory to the position of the trees in integrated 
systems (KRUSCHEWSKY, 2012). Dung deposition may be concentrated in certain locations according to the arrangement of these grazing conditioners. Forest litter and animal excreta represent the main return route of nutrients to the ecosystem through decomposition by microorganisms (SOUZA et al., 2018). Animals in pastures accelerate the nutrient cycling process in the ecosystem, the major part $(90 \%)$, including nitrogen and potassium, going back to soil via excreta (RICHARDS \& WOLTON, 1976; LANTINGA et al., 1987). Parenthetically, knowing how these excreta are returned to the soil is of utter importance. Many factors can affect the spatial distribution of dung in the paddock, including meteorological factors such as air temperature, rainfall and solar radiation while grazing, and the location of the cow drinker, gate, trees, salt trough and resting area (WHITE et al., 2001). In pasture, uniformity of excreta distribution is the main factor that affects the balance between the inputs and outputs of this agroecosystem and; consequently, the recommendations for nutrient replacement by means of fertilization. This heterogeneity of soil fertility, as well as the irregularity of forage production, in these environments is developed and maintained by selective grazing imposed by the animal (HIRATA et al., 2002).

If the excreta are homogeneously distributed, nutrient distribution will be effective. However, in conventional pastures, the distribution pattern in which nutrients are returned to pasture in the form of feces and urine is not uniform (FERREIRA et al., 2011). Nonetheless, in silvopastoral systems, organic matter cycling gains synergy: trees withdraw nutrients from the deeper layers and deposit them on the soil in the form of litter; cattle then deposit their excretions in a more homogeneous distribution pattern (FERREIRA et al., 2011; KRUSCHEWSKY, 2012). This happens because in an adequately wooded pasture, "comfort features" such as shade, dry and soft floor, and scalers (tree trunks - which enable animals to exercise naturally against ectoparasites and flies, when used to scratch themselves) are well spread throughout the area.

Dung and urine patches also increase with a higher stocking density (MOIR et al., 2011). There is a high correlation between the percentage of defecation and the dwell time of animals in feeding, milking and grazing areas (WHITE et al., 2001). According to the authors, shading and watering positions have a great effect on behavior and the distribution of dung in warmer environments because they can provide better environmental conditions for dairy cows. So, the aim of this study was to map the distribution of feces from dairy heifers in sunny and shaded areas.

\section{MATERIALS AND METHODS}

This experiment carried out at the Embrapa Agrossilvopastoral Research Center, in Sinop, Mato Grosso State, Brazil (11 ${ }^{\circ} 51^{\prime} 43^{\prime}$ S, $55^{\circ} 35^{\prime} 27^{\prime}$ ' W, $384 \mathrm{~m}$ a.s.1.). The experimental area comprised 10 ha of flat contour land on a Typic Hapludox, clay, caulinitic, isothermic soil (SOIL SURVEY STAFF, 1999). The soil presented medium fertility, phosphorus and limestone being initially adjusted. The region's climate is a tropical humid Am type, with average annual temperature of $25^{\circ} \mathrm{C}$, relative humidity of $76 \%$ and annual precipitation of $2,000 \mathrm{~mm}$. Weather data for the experimental period (Figure 1) were recorded at the Sinop weather station (AGRITEMPO, 2018).

A eucalyptus clone H13 (E. urophylla $\times$ E. grandis) was planted in an east-west direction in January 2010. The arrangement of the eucalyptus trees allowed two shading patterns. One of the areas did not receive trees, composing the treatment without shade (control without trees). In the system with moderate shading, the trees were planted in double rows at the edges of the paddock (338 trees $\mathrm{ha}^{-1}$ ). In the intense shading system, the trees were distributed in triple rows spaced at $15 \mathrm{~m}$ (714 trees $\left.\mathrm{ha}^{-1}\right)$. The treatments were distributed in randomized complete blocks with three replications. All systems had the same pasture area, justifying the differences in total width (same length) between the areas $(49,59$ and $84 \mathrm{~m}$, respectively). The pasture was sown with maize in February 2011. Maize harvest took place in April, when the pasture had finished its formation process. Pastures had a period of adaptation to the grazing strategy, with evaluations eventually initiated in December 2012. Urea fertilization was divided into two applications of $40 \mathrm{~kg} \mathrm{~N} \mathrm{ha}^{-1}$ each time (November 2012 and February 2013).

The experimental period ran from December 2012 up to June 2013, divided into three data collection periods based on the rainfall distribution: rainy period $=$ December 2012; transition period $=$ March 2013 and dry period $=$ June 2013. The rainfall distribution was about $80 \%, 20 \%$ and $0 \%$ of the total rainfall during the respective periods.

The pre-grazing target was $95 \%$ light interception (LI) in all systems (FONSECA et al., 2012), and post-grazing height was adjusted to at least $50 \%$ of the pre-grazing height (CARVALHO et al., 2009). The sward surface height was evaluated when these points were identified. Three paddocks from each system were used as sampling units for each treatment for three consecutive days. The 


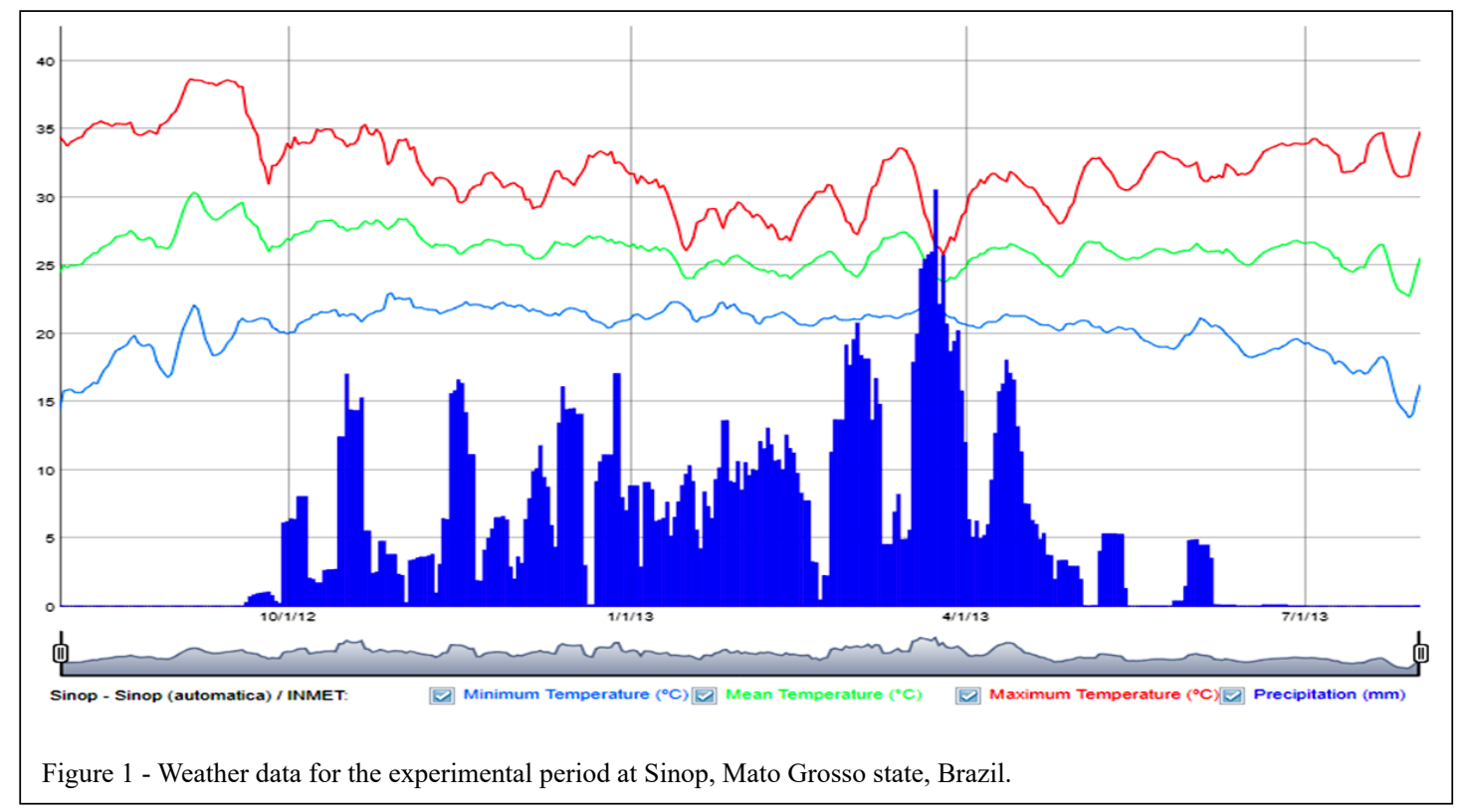

animals used were crossbred heifers (Holstein $\times$ Gir) with a body weight of $350 \mathrm{~kg}$.

Pre-grazing herbage mass was evaluated after height measurement, and residual herbage mass was collected after grazing. Three squares of $0.5 \mathrm{~m}^{2}$ were cut in each paddock in representative places. The samples were dried in an oven for $72 \mathrm{~h}$.

Animal behavior assessments were performed at $15 \mathrm{~min}$ intervals, starting at 8:30 a.m., with readings ending at 4:00 p.m. In this time interval, it was possible to detect the movement of the animals caused by the presence of the sun and high temperatures. The location variables were: (1) sun exposure or (2) permanence in the shade, and the activities were: (1) grazing (MELLO et al., 2017); (2) walking; (3) visiting the water point; (4) idleness; and (5) ruminating. Water drinking fountains were available firstly outside only and eventually both inside and outside the paddocks. The temperature was measured with mini meteorological stations allocated in the full sun system and between tree ranks. Data collection happened every $15 \mathrm{~min}$ and was automatically registered.

Paddocks were georeferenced using a Garmin ETREX 30 GPS. The GPS precision was $25 \mathrm{~m}$ off the exact geographic point; however, most important was the relative location, for which the GPS had high precision (centimeters). The SMS Advanced program from Ag Leader was used to divide the 25 sample small squares (grids) (TURNER et al., 2000). These grids measured $10 \times 10 \mathrm{~m}, 12 \times 10 \mathrm{~m}$ and 15 $\times 10 \mathrm{~m}$ in the full sunlight, moderate shading and intense shading systems, respectively. Sizes were variable according to the size of the main paddock.

Pasture litter was evaluated in grids and considered all forage wasted by the animals that was detached from the clump but which was not consumed and was deposited on the soil. This forage is considered pasture litter when the residual forage mass is not trapped and thus will no longer be recycled by the original plant, only by decomposition in the soil, as it is deposited on the surface. In every grid, a square frame $\left(1 \mathrm{~m}^{2}\right)$ was set at the central point to collect and evaluate wasted forage in the grassland by animal activity except the residual forage mass (CARNEVALLI et al., 2006).

The dung patches were counted and located using a GPS gadget. After the heifers finished the grazing period, the observer went around the paddock and, for every step they took, looked for a patch of feces and got every single one inserted into the GPS system. Dung patch distribution was mapped with the Quantum GIS program using the isoline map method (Quantum GIS, 2015).

The data about pasture structure and animal behavior were analyzed using the combined experiments technique (MOORE \& DIXON, 2015), in which each system was considered as an independent experiment. The replicates were the sample paddocks $(n=3)$, and the sources of variation were the systems and the evaluation periods. Each source of variation was studied by combining experiments with similar

Ciência Rural, v.49, n.10, 2019. 
characteristics. Within the experiments, the data were analyzed using SAS ${ }^{\circledR}$ Mixed Procedure, with repeating measures and using the restricted maximum likelihood method (REML). The comparison of means, as required, was performed using the PDIFF method with a $5 \%$ probability level.

\section{RESULTS AND DISCUSSION}

Temperature is an important factor in conditioning an animal's behavior and its location. Shaded systems reported temperatures $5-7{ }^{\circ} \mathrm{C}$ less than that of the full sunlight system $(\mathrm{P}=0.0028)$. However, the temperature of the shaded region was similar between both shade systems $(\mathrm{P}=0.1857)$. The system with more trees (intensive shade) could reduce the wind speed, though this was not enough to cause any harm to the animals (VARELLA et al., 2016). The maximum temperatures during this experiment were 35,32 and $34{ }^{\circ} \mathrm{C}$ during the rainy, transition and early dry periods. The relative humidity was $70-90 \%$ from rainy to early dry seasons.

The pre-grazing herbage mass and residual herbage mass ( $\left.\mathrm{kg} \mathrm{DM} \mathrm{ha}{ }^{-1}\right)$ and pre- and post-grazing sward surface height were affected by the evaluation period (Table 1). When the piatã grass reached $95 \%$ $\mathrm{LI}$, the forage canopy reached an average height of $46.8 \mathrm{~cm}$ in the first grazing period. Over time, the canopy height decreased and stabilized, to 36.9 and $35.3 \mathrm{~cm}$ in the second and third periods, respectively. The reduction in plant height was caused by adaptation of the pasture to the management by LI. DIAS-FILHO (2012) obtained values in the order of $35 \mathrm{~cm}$ for pre-grazing sward surface height for piatã in Campo Grande, MS. NANTES et al. (2013) concluded that piatã grass, in a full sunlight system, shows good management flexibility between heights of 15 and $45 \mathrm{~cm}$, noting a difference between dry matter mass, with similar average daily gains between these different heights of management.

The pasture litter was affected by shade treatments, despite the values being very low for all systems because of the management strategy based on LI which controls the sward structure, avoiding stem growth and leaf senescence (CARNEVALLI et al., 2006). For all periods, the full sunlight system had the most considerable pasture litter $(21 \mathrm{~kg}$ DM $\left.\mathrm{ha}^{-1}\right)$ when compared to the shaded system $(16 \mathrm{~kg}$ $\left.\mathrm{DM} \mathrm{ha}{ }^{-1}\right)(\mathrm{P}=0.0088)$ except when, in the early dry season, the moderate shade system showed the same amount of pasture litter as the full sunlight system $\left(23 \mathrm{~kg} \mathrm{DM} \mathrm{ha}^{-1}\right)(\mathrm{P}>0.0050)$. The highest amounts of wasted herbage were mostly concentrated close to cow drinkers and the gate in the full sunlight system, during the rainy season. This structural feature appears to be a consequence of cattle behavior that distributes feces in these places in the full sunlight system.

Grazing activity is harmed by the unsuitable conditions under full sunlight but made pleasant by the presence of trees (MELLO et al., 2017). According to DASH et al. (2016), high temperature associated with high relative air humidity directly affects animal comfort and physiological functions, and harms animals' daily routine. When the daily routine of an animal is disturbed, reduced performance can be expected as a stressed animal has increased body temperature, respiratory rate and sweating. The heifers revealed a tendency to return to grazing activity under the full sunlight system during the hottest time of the day when rumination and idleness decreased; but, as this action was impossible because of the high temperatures and solar radiation, the animals would return to the cow drinker until later on (MELLO et al., 2017). During the transition period,

Table 1 - Pre-grazing and residual herbage mass (HM) and sward surface height (SSH) of piatã grass under shading during the experimental period.

\begin{tabular}{|c|c|c|c|c|}
\hline & \multicolumn{2}{|c|}{------------------------'Pre-grazing--------------------------- } & \multicolumn{2}{|c|}{ 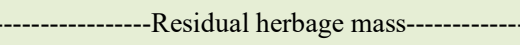 } \\
\hline & $\mathrm{HM}\left(\mathrm{kg} \mathrm{DM} \mathrm{ha}^{-1}\right)$ & $\mathrm{SSH}(\mathrm{cm})$ & $\mathrm{HM}\left(\mathrm{kg} \mathrm{DM} \mathrm{ha}^{-1}\right)$ & $\mathrm{SSH}(\mathrm{cm})$ \\
\hline Rainy period & $6,156 \mathrm{~A}$ & $46.8 \mathrm{~A}$ & $4,869 \mathrm{~A}$ & $31.4 \mathrm{~A}$ \\
\hline Transition & $4,169 \mathrm{AB}$ & $36.9 \mathrm{~B}$ & $4,165 \mathrm{~A}$ & $23.5 \mathrm{~B}$ \\
\hline Dry period & $2,783 \mathrm{~B}$ & $35.3 \mathrm{~B}$ & $2,867 \mathrm{~B}$ & $24.5 \mathrm{~B}$ \\
\hline MSE & 501 & 0.76 & 402 & 0.76 \\
\hline $\mathrm{P}$ & 0.0118 & 0.0109 & 0.0080 & 0.0001 \\
\hline
\end{tabular}

Averages followed by the same letter are not significantly different, between lines $(\mathrm{P}<0.050)$. 
the full sunlight and moderate shade systems reported a similar frequency of animals in idleness (27\%), greater than in the intensive shade system $(20 \%)$ $(\mathrm{P}=0.0001)$. However, during the early part of the dry period, the full sunlight system showed increased frequency of animal idleness $(29 \%)$ as compared to that in other systems $(16 \%)(\mathrm{P}<0.0001)$. The animals' activities directly affected the locations in which they chose to remain. They also tended to defecate in greater volume, altering the dung distribution.

Feces patch distribution was affected by the different systems, during the rainy period $(\mathrm{P}=0.0165)$. In this period, both differences between grids in the paddocks $(\mathrm{P}=0.0090)$ and interaction effects between grids and systems $(\mathrm{P}=0.0025)$ were observed. In the full sunlight system, there was a higher feces patch concentration in places close to the gate (Figure 2a). There was a feces patch concentration around the cow drinker outside the paddock because the heifers spent a higher portion of their time in this place during the hottest hours of the day. In this place, the animals refreshed themselves by floating inside the cow drinker and lying down in muddy places. This activity added water to the muddy puddles of rainwater, which were places highly preferred by heifers to refresh themselves during days with high relative humidity (87\%) and temperature $\left(35-36{ }^{\circ} \mathrm{C}\right)$. According to GERALDO et al. (2012), a muddy place can act as an

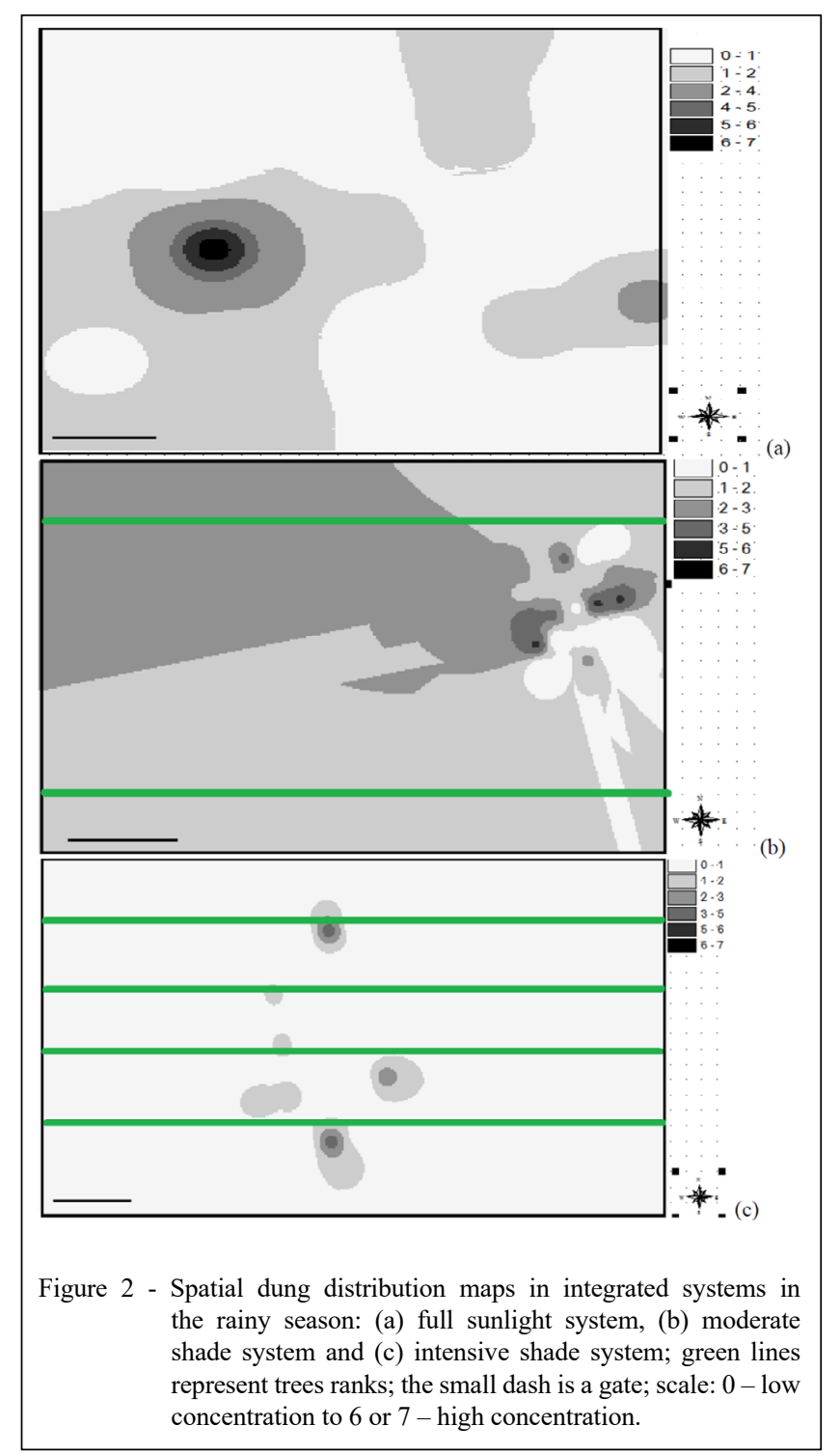

Ciência Rural, v.49, n.10, 2019. 
alternative to provide relief from warmer temperatures in the absence of shade. SCHUTZ et al. (2010), in their experiment in temperate regions, observed that the time spent around the cow drinker increased when no shade was provided to the animals. In the no shade system, cows spent more time standing during the day compared to those under shade, possibly to increase radiation from the body to keep it cooler. They also tended to crowd around cow drinkers, with some cows even standing with their front feet dipped in the water, trying to splash water from the trough over their backs (MULLER et al., 1994). The heifers showed no movements (61\%), mainly during the hot hours.

In the moderate shade system, the major concentration points were the central place and the shaded place where more grazing activity occurred (Figure 2b). The heifers ruminated and/or were idle in the gate outside the paddock where there was shade as well. Grazing, rumination and idleness in the shaded places conditioned this higher dung concentration. In the subtropical region, the trees also modified the frequency and time spent grazing and in idleness, but it did not influence the frequency and time spent ruminating (SOUZA et. al., 2010).

In the intensive shade system, the feces patches were distributed close to shaded areas (Figure $2 \mathrm{c}$ ). These shaded places were the favorites to ruminate and be idle, when the heifers defecated more.

During the transition period, there was a greater feces concentration in the central point in the full sunlight system, being like the other places observed in the rainy season (Figure 3a). However, the points were not quite concentrated because the animals searched for a cow drinker outside. In the

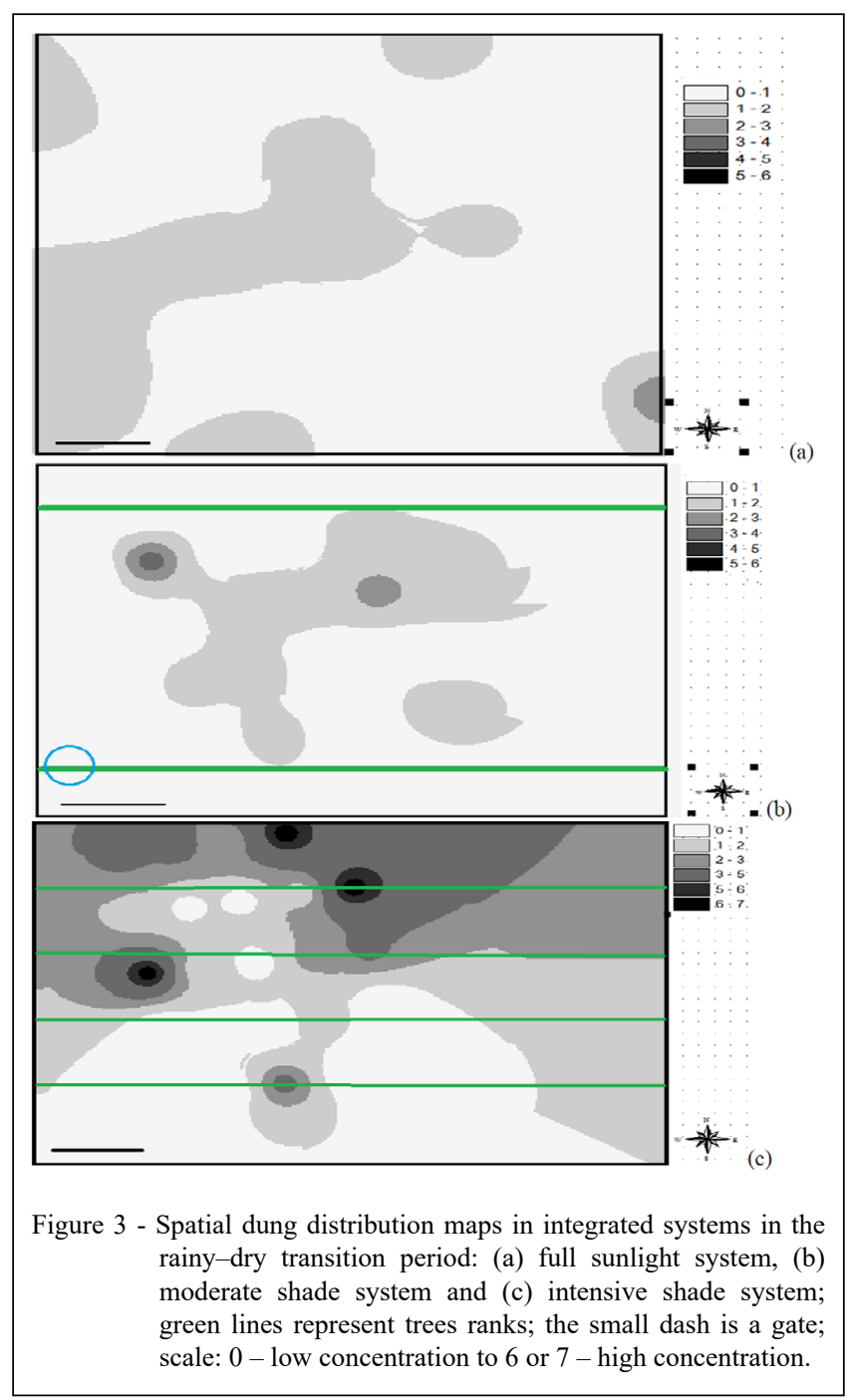

Ciência Rural, v.49, n.10, 2019. 
moderate system, the dung was not distributed under trees, but in the places under their influence where the animals spent time ruminating and in idleness (Figure $3 b)$. In the intensive shade system, the distribution of feces patches was higher within the paddock in the transition period when compared to the rainy season, but the concentrated areas were still under or close to trees (Figure 3c). KRUSCHEWSKY et al. (2012) evaluated dung distribution in Tanzanian pastures shaded by Grevillea robusta $(20 \times 5 \mathrm{~m})$ and in Mombaça pastures without trees for shade. In full sunlight, the highest feces deposition was close to the gate and cow drinker and, in the shaded pastures, the distribution was uniform despite there being some small concentrations at the same points.
Later on, during the early dry season, all systems showed a large concentration close to the cow drinker. At this time, the heifers were more likely to drink water inside the paddock rather than from the outside trough (Figure 4a). In the shaded systems, the trees still influenced the heifers because there was some concentration under the trees, and the animals spent more time there (Figure $4 \mathrm{~b}$ and $4 \mathrm{c}$ ). The grids that had a higher feces concentration were also the most crowded ones and had significant pasture litter. This could be explained by two reasons. The first one could be because the animals often lie down and trample around, damaging the pasture. The second reason could be defecation happening more often in such places and animals avoiding grazing in the

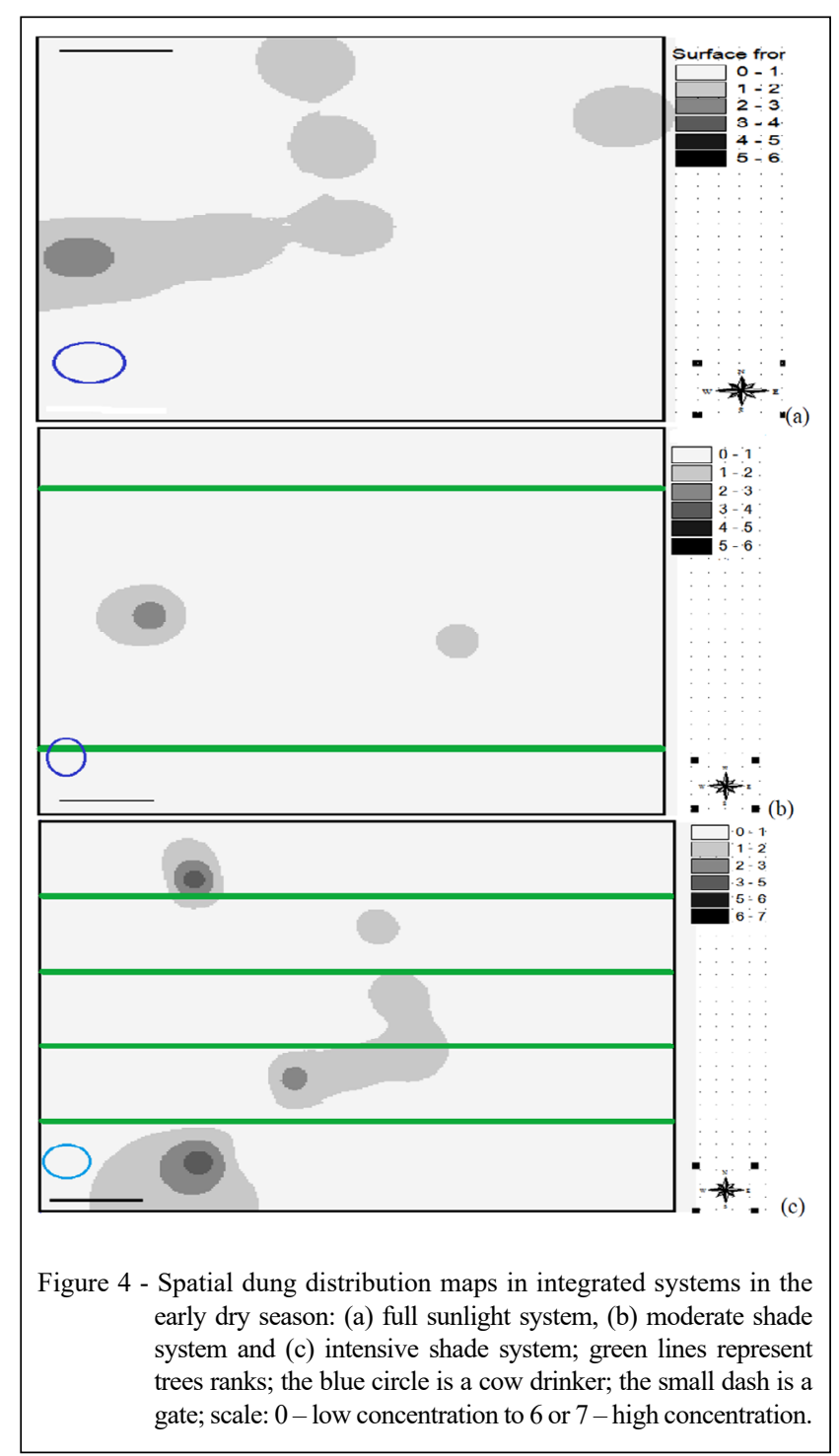

Ciência Rural, v.49, n.10, 2019. 
surroundings. However, most possibly, both reasons could be happening simultaneously.

Higher feces concentrations were found at different points according to the system in question. In the full sunlight system, the main place was near the gate and the cow drinker, while in the shaded systems the main place was in areas under the influence of shade. FERREIRA et al. (2011) researched Brachiaria brizantha pastures grazed by 22 heifers and 22 crossbred dairy cows in four conditions: full sunlight; just one artificial shade point in the pasture; a grove in the pasture; and dispersed shade with trees throughout the pasture. They discovered a greater concentration of feces patches close to the gate and cow drinker when the animals were in the full sunlight system. This concentration was higher under artificial shade when the animals were in this system. In the pastures with trees, $72 \%$ of the feces were located under the trees, indicating that the animals spent more time in the shaded areas rather than in the sunny ones. The shade conditioned the grazing and modified the dung dispersion. KRUSCHEWSKY et al. (2012) monitored the dung distribution of 35 dairy heifers in paddocks with native trees and in full sunlight systems according to the dispersion index, verifying that full sunlight pastures showed areas with higher concentrations of feces patches, while in the shaded area these patches were more dispersed and uniform. Feces was not only deposited just under the trees as popular knowledge states, nor was feces distribution uniform in places in full sunlight. When the pasture has a shaded area available, animals switch their resting place, with no occurrence of damaged spots as normally happens in pastures with only one tree or shade point. It is true that herbage density decreases when the pasture is shaded, but this can be controlled by planting trees with appropriate spacing, allowing enough light to penetrate and for the sward to grow.

\section{CONCLUSION}

In tropical conditions, dairy heifers use shaded areas for lying down to idle or ruminate during the hottest hour of the day. Moderate shading in the pasture is sufficient for maintaining the daily activities of dairy heifers. Shaded pastures have a more homogeneous spatial dung distribution, despite some small points of concentration still being present in areas such as around the cow drinkers and the gate. Thus, the shading of pastures is recommended for tropical conditions to improve the spatial dung distribution in dairy farms.

\section{ACKNOWLEDGEMENTS}

The authors thank the Conselho Nacional de Pesquisa (CNPq), Brasil for funding the project REPENSA 562666/2010; Empresa de Pesquisa Agropecuária (Embrapa) for funding in the Project 02.11.05.011.00.00 and Coordenação de Aperfeiçoamento de Pessoal de Nível Superior (CAPES), Brasil - Finance.

\section{DECLARATION OF CONFLICT OF INTERESTS}

The authors declare no conflict of interest. The founding sponsors had no role in the design of the study; in the collection, analyses, or interpretation of data; in the writing of the manuscript, and in the decision to publish the results.

\section{AUTHORS' CONTRIBUTIONS}

Roberta Aparecida Carnevalli conceived and designed experiments, got funding, implemented experimental area, trained students, analyzed data and wrote the paper; Andrea Cristina Tavares de Mello carried out field experiments, processed and analyzed data, defended her master's degree; Luciano Shiratsuchi supported spatial data analysis; Steben Crestani; Admar Junior Coletti and Camila Eickstein helped in conducting the experiment and collecting data. All authors critically revised the manuscript and approved of the final version.

\section{BIOETHICS AND BIOSSECURITY COMMITTEE APPROVAL}

Statement of animal rights: The authors whose names are listed above certify that they have not committed a willful act of abuse or cruelty or neglected the rights of the animals included in this study. The Ethics Committee for Animal Use of Embrapa Agrosilvopastoral, Sinop, Mato Grosso state, Brazil, approved the study under number 003/2015.

\section{REFERENCES}

AGRITEMPO, 2018. Available from: <https:/www.agritempo. gov.br/agritempo/jsp/Estatisticas/index.jsp?siglaUF $=M T>$. Accessed: Jan. 15, 2019

CARNEVALLI, R.A. et al. Herbage production and grazing losses in Panicum maximum cv. Mombaça pastures under four grazing managements. Tropical Grasslands, 40(3) 165-176, 2006. Available from: <http://www.tropicalgrasslands.info/public/ journals/4/Historic/Tropical\%20Grasslands\%20Journal $\% 20$ archive/PDFs/Vol_40_2006/Vol_40_03_2006_pp165_176.pdf>. Accessed: Jun. 01, 2018.

CARVALHO, P.C.F. et al. Do bocado ao pastoreio de precisão: compreendendo a interface planta-animal para explorar a multifuncionalidade da pastagem. Revista Brasileira de Zootecnia, v.38, p.109-122 (supl. Especial). Available from: <https://www. lume.ufrgs.br/bitstream/handle/10183/107079/000712682. pdf? sequence=1\&isAllowed=y $>$. Accessed: Aug. 02, 2019.

DASH, S. et al. Effect of heat stress on reproductive performances of dairy cattle and buffaloes: A review. Vet World. 9, n.3, p.235244, 2016. Available from: <https://www.ncbi.nlm.nih.gov/pmc/ 
articles/PMC4823282/pdf/VetWorld-9-235.pdf>. Accessed: Aug. 02, 2019. doi: 10.14202/vetworld.2016.235-244.

FERREIRA, L.C.B. et al. The effect of different shading availabilities dispersion of feces of cattle in the pastures. Rev. Bras. de Agroecologia, v.6, n.1, p.137-146, 2011. Available from: $<$ http://orgprints.org/23308/1/Ferreira Efeito.pdf $>$. Accessed: Dec. 12,2018

FONSECA, L. et al. Management targets for maximizing the shortterm herbage intake rate of cattle grazing in Sorghum bicolor. Livest. Sci. v.145, p.205-211. 2012. Available from: <https:// www.sciencedirect.com/science/article/pii/S1871141312000595>. Accessed: Dec. 12, 2018. doi: 10.1016/j.livsci.2012.02.003.

GERALDO, A.C.A.P.M. et al. What do cattle prefer in a tropical climate: Water immersion or artificial shade? Journal of Life Sciences, v.6, p.1356-1362, 2012. Available from: <http:// dspace.uevora.pt/rdpc/bitstream/10174/8498/1/What\%20Do\%20 Cattle\%20Prefer\%20in\%20a\%20Tropical\%20Climate-\%20 Water\%20Immersion\%20or\%20Artificial\%20Shade.pdf $>$. Accessed: Dec. 12, 2018.

HIRATA, M. et al. Effects of progressive grazing of a pasture on the spatial distributions of herbage mass and utilization by cattle: a preliminary study. S. Ecol. Res. (2002) 17: 381. Available from: $<$ https://doi.org/10.1046/j.1440-1703.2002.00496.x>. Accessed: Dec. 12,2018

KRUSCHEWSKY, G.C. et al. Effect of the presence of trees in the behavior of dairy cows, a case study in the region Sandstone Caiuá/ PR. 2012. Revista Brasileira de Agroecologia. Available from: $<$ http://www.aba-agroecologia.org.br/revistas/index.php/cad/article/ viewFile/11421/7243>. Accessed: Dec. 12, 2018.

LANTINGA, E. A. et al. Distribution of excreted nitrogen by grazing cattle and its effects on sward quality, herbage production and utilization. Animal manure on grassland and fodder crops. Fertilizer or waste? v.30,p.103-117, 1987. Available from: $<$ https:// link.springer.com/content/pdf/10.1007\%2f978-94-009-3659-1. pdf $>$. Accessed: Dec. 12, 2018

MELLO, A. C. T. et al. Improved grazing activity of dairy heifers in shaded tropical grasslands. Ciência Rural, Santa Maria, v.47, n.2, 2017. Available from: <http://www.scielo.br/pdf/cr/v47n2/16784596-cr-47-02-e20160316.pdf>. Accessed: Jun. 01, 2018.

MOIR, J. L. et al. The spatial coverage of dairy cattle urine patches in an intensively grazed pasture system. The Journal of Agricultural Science, v.149, p.473-480, 2011. Available from: $<$ https:/www.cambridge.org/core/services/aop-cambridge-core/ content/view/B96849B475D2E5FEFB14B9BC25FB5204/ S0021859610001012a.pdf/spatial_coverage_of_dairy_cattle urine_patches_in_an_intensively_grazed_pasture_system.pdf $>$. Accessed: Jan. 10, 2019. doi: 10.1017/S0021859610001012.
MOORE, K.J., DIXON, P.M., 2015. Analysis of combined experiments revisited. Agron. J. 107, 763-771. <http://dx.doi. org/10.2134/agronj13.0485>. Accessed: Jun. 10, 2015.

MULLER, C.J.C. et. al. Effect of shade on various parameters of Friesian cows in a Mediterranean climate in South-Africa 3. Behavior, South African, Journal of Animal Science, v.24, n.2, p.61-66, 1994. Available from: <https://www.ajol.info/index.php/ sajas/article/view/138379/127947>. Accessed: Dec. 10, 2018.

RICHARDS, I. R.; WOLTON, K. M. The spatial distribution of excreta under intensive cattle grazing. Grass and Forage Science, v.31, 8992, 1976. Available from: <https://doi.org/10.1111/j.1365-2494.1976. tb01123.x>. Accessed: Dec. 10, 2018

SCHUTZ, K.E.; ROGERS, A.R. et al. The amount of shade influences the behavior and physiology of dairy cattle. Journal of Dairy Science, v.93, p.125-133, 2010. Available from: <https:// www.sciencedirect.com/science/article/pii/S0022030210702721>. Accessed Dec. 10, 2018. doi: 10.3168/jds.2009-2416.

Soil Survey Staff. 1999. Soil taxonomy: A basic system of soil classification for making and interpreting soil surveys. 2nd edition. Natural Resources Conservation Service. U.S. Department of Agriculture Handbook 436. Available from: <https://www.nrcs. usda.gov/wps/portal/nres/main/soils/survey/class/taxonomy/>. Accessed: Dec. 10, 2018.

SOUZA, M. DE S.; et al. Ciclagem de nutrientes em ecossistemas de pastagens tropicais. PUBVET, v.12, n.5, a.91, p.1-9, Mai., 2018. Available from: <http://www.pubvet.com.br/artigo/4804/ ciclagem-de-nutrientes-em-ecossistemas-de-pastagens-tropicais $>$. Accessed: Dec. 10, 2018.

SOUZA, W. et al. Behavior of beef cattle in silvopastoral systems with eucalyptus. Revista Brasileira de Zootecnia, v.39, n.3, p.677-684, 2010. Available from: <http://www.scielo. br/scielo.php?pid=S1516-35982010000300029\&script $=\mathrm{sci}$ arttext\&tlng=pt>. Accessed: Dec. 10, 2018.

TURNER, L.W. et al. Monitoring cattle behavior and pasture use with GPS and GIS. Can. J. of An. Sci., v.80, n.3, p.405-413, 2000. Available from: <https://www.nrcresearchpress.com/doi/ pdf/10.4141/A99-093>. Accessed: Dec. 10, 2018.

VARELLA,A.C.et al. Silvopastoral systems in the cold zone of Brazil. Springer Int. Publishing. p.231-256, 2016. Available from: $<$ https:// link.springer.com/chapter/10.1007/978-3-319-24109-8 10>. Accessed: Dec. 10, 2018. doi: 10.1007/978-3-319-24109-8_10.

WHITE, S.L. et al. Spatial and time distribution of dairy cattle excreta in an intensive pasture system. J. of Environmental Quality, v.30, n.6, p.2180-2187, 2001. Available from: <https:// dl.sciencesocieties.org/publications/jeq/abstracts/30/6/2180>. Accessed: Dec. 10, 2018. doi: 10.2134/jeq2001.2180. 